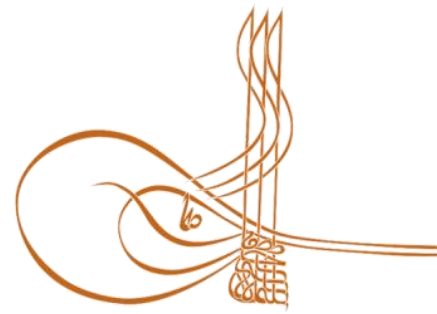

www.turkishstudies.net/economy
Turkish Studies - Economics, Finance, Politics

eISSN: 2667-5625

Research Article / Araștırma Makalesi

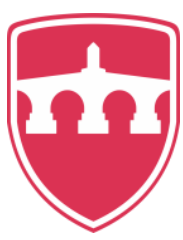

INTERNATIONAL BALKAN

UNIVERSITY

Sponsored by IBU

\title{
Uluslararası İşletmecilik Perspektifinden Politik Risk: Türleri, Değerlendirilmesi ve Yönetimi *
}

\author{
Political Risk from the Perspective of International Business: Types, Assessment and Management
}

\author{
Onur Başar Özbozkurt **
}

\begin{abstract}
Local companies have exponentially initiated to run their business activities abroad within the effect of globalization. There are a few determinants that underlie at the background of these businesses' desire for internationalization. In this respect, political risk has been drawn attention due to having a crucial role in running business activities and selecting the most optimal location. From this point of view, the present study aimed at being fulfilled a clear the need of research specifically in Turkish literature in the scope of being identified the political risk phenomenon and its types which companies might be exposed in the process of international business activities and risk avoidance via carrying out risk assessment or turning the risk into an opportunity or minimizing the risk through appropriately managing it. It has been seen that the types of political risk consist of general instability risk, ownership and control risk, operational risk, and transfer risk within the frame of the study. Additionally, it has been determined that political risk assessments fundamentally include three steps such as the assessment of issues of relevance to the firm, potential political events, and probable impacts and responses. Moreover, integrative strategies, protective and defensive strategies, and combination strategies have been principally remarked in the sense of political risk management. In this regard, it has been signified that political risk insurance, gradually increasing business activities, joint venture with local company and providing local employment, developing closer relationships with the host country dynamics and using local financing, operational hedging (setting up multiple plants to spread risk), and addressing legal bodies have been drawn attention as sub-strategies.
\end{abstract}

Structured Abstract: Today, many companies try to grow by spreading their activities outside the borders of their own countries. In this respect, according to the literature on internationalization, there are five basic ways of expanding into the international market which is export, licensing, franchising, joint venture, and whollyowned subsidiary (Costa \& Figueira, 2017: 69), and companies might confront the four main risks that include

\footnotetext{
* Bu çalışma, 30.06.2016 tarihinde, Çağ Üniversitesi Sosyal Bilimler Enstitüsü İşletme Yönetimi Anabilim Dalı’nda yazar tarafindan tamamlanmış olan, "Uluslararası İşletmecilik Faaliyetlerinde Politik Risk Yönetim Stratejilerinin Oluşturulması ile İlgili Türk İş Dünyası ve Yatırımcıların Algısı Üzerine Nitel Bir Araştırma” başlıklı doktora tezinin ilgili bölümlerinin güncellenerek yeniden ele alınmasıyla hazırlanmıştır.

** Dr. Öğr. Üyesi, Tarsus Üniversitesi, Meslek Yüksekokulu, Büro Yönetimi ve Yönetici Asistanlığ

Assist. Prof. Dr., Tarsus University, Higher Vocational School, Bureau Management and Executive Assistantship

ORCID 0000-0002-2325-2433

onurozbozkurt@tarsus.edu.tr

Cite as/ Atıf: Özbozkurt, O. B. (2020). Uluslararası işletmecilik perspektifinden politik risk: türleri, değerlendirilmesi

ve yönetimi, Turkish Studies - Economy, 15(1), 411-428. https://dx.doi.org/10.29228/TurkishStudies.40446

Received/Geliş: 06 January/Ocak 2020

Checked by plagiarism software

Accepted/Kabul: 25 March/Mart 2020

Published/Yayın: 30 March/Mart 2020

Copyright $(C)$ INTAC LTD, Turkey

CC BY-NC 4.0
} 
commercial risk, financial risk, socio-cultural risk and political risk in the process of business activities (Menipaz \& Menipaz, 2011: 151-152).

From this point of view, it has been considered that the political risk that means the risk type which has the most destructive effect in the frame of business activities, is the possibility in the political environment will directly or indirectly induce business activities in negative or positive ways (John \& Lawton, 2018: 848). In other words, as Haendel (2018: 14) emphasize that the political risk can be signified as the risk or probability of occurrence of some political event in the host country that will affect business activities and profitability. Similarly, Musonera (2008: 2) highlights that political risk relates to the possibility of changes in the business environment, and to the possibility that these changes can adversely affect operating profits as well as the value of assets of foreign companies.

In this sense, although political risk, which destructively affect the international business activities, has been a remarkable phenomenon specially in the world since the twentieth century (Sun \& Liu, 2018: 50), it has not been drawn much attention in up-to-date studies and it has been seen that there are limited number of studies related to political risk. In this respect, the present study aimed at being fulfilled a clear the need of research specifically in Turkish literature in the scope of being identified the phenomenon and its types which companies might be exposed in the process of international business activities and risk avoidance via carrying out risk assessment or turning the threats into an opportunity or mitigating the risk through appropriately managing it.

As a result of the study, it has been noted that the types of political risk consist of general instability risk, ownership and control risk, operational risk, and transfer risk (Root, 1987: 132). In this frame, general instability risk is related to the uncertainty about the future viability of host country's political system. In contrast, ownership/control risk is related to the possibility that a host government might take action (e.g., expropriation) to restrict an investor's ownership and control of a subsidiary in that host country. Operation risk proceeds from the uncertainty that a host government might constrain the investor's business operations in all areas, including production, marketing, and finance. Finally, transfer risk applies to any future acts by a host government that might constrain the ability of a subsidiary to transfer payments, capital, or profit out of the host country back to the parent firm (Onkvisit \& Shaw, 2004: 101).

Additionally, it has been determined that political risk assessments fundamentally include three steps such as the assessment of issues of relevance to the firm, potential political events, and probable impacts and responses (Hollensen, 2007: 195). Clearly, the assessment of issues of relevance to the firm is a prioritized assessment of the crucial economic and business issues. Moreover, the assessment of potential political events requires an assessment of relevant political events, their probability of occurrence, their impact and the willingness/ability of the government to respond to them. Also, the assessment of probable impacts and responses requires an impact assessment of probable scenarios and possible responses to initial and ultimate risks (Lee \& Carter, 2012: 46).

Furthermore, it has been remarked that integrative strategies, protective and defensive strategies, and combination strategies have been particularly preferred in the sense of political risk management (Collinson, Hodgetts \& Rugman, 2006: 394-395). In this regard, integrative strategies are designed to help the subsidiary to become one with the host country's needs and culture. Protective and defensive strategies are designed to discourage the host government from interfering in operations. In contrast to the integrative strategies, these encourage the non-integration of the subsidiary in the host country environment (Aswathappa, 2008: 127). Besides, combination strategies are related to both integrative and protective/defensive strategies to manage the political risks of going or being abroad (Suder, 2009: 97-98).

In this respect, it has been seen that political risk insurance, gradually increasing business activities, joint venture with local company and providing local employment, developing closer relationships with the host country dynamics and using local financing, operational hedging, and addressing legal bodies have been drawn attention as sub-strategies to manage political risk. In this sense, the key tool for mitigating political risk is the purchase of political risk insurance. It protects against the risk that actions of foreign governments or political groups will negatively impact what were otherwise sound commercial investments. It typically includes coverage for the various kinds of political risks, like nationalization and expropriation of assets, restriction on remittances, political violence and war damages, currency inconvertibility, and breach of contract (Mayer, 2017: 7) 
Also, companies minimize risk and uncertainties via gradually increasing its business activities to analyze external environment circumstances. Furthermore, the local community may be concerned that a foreign company will extract materials and labor and make a profit but fail to give something back to the local environment and the local people. Therefore, the company needs to be a good "local citizen" and reinvest in the local community (Hollensen, 2014: 219). Besides, companies develop close ties with the host country to reduce the risk, setting up multiple plants to spread risk (Hub Guides, 2013: 1-4) and addressing the judicial organs to manage political risks (MIGA, 2013: 37).

Keywords: Internationalization, Host Country, Political Risk, Risk Mitigation

Öz: Küreselleşmenin etkisiyle, yerel olarak faaliyette bulunan işletmeler, giderek artan oranda, yurt dışında işletmecilik faaliyetlerinde bulunmaya başlamıştır. İşletmelerin bu uluslararasılaşma arzularının arka planında yer almakta olan bir dizi belirleyici bulunmaktadır. Bu açıdan, faaliyetlerin gerçekleştirilmesinde ve uygun lokasyon seçiminde politik risklerin kilit bir rol oynamakta olduğu dikkat çekmektedir. Buradan hareketle bu çalışmada, uluslararası işletmecilik faaliyetleri sürecinde, işletmelerin maruz kalabilecekleri politik risk olgusu ile türlerinin tanımlanması ve risk değerlendirmelerinin de gerçekleştirilerek riskten kaçınılması ya da riski doğru bir şekilde yöneterek riskin firsata çevrilmesi veya minimize edilmesi bağlamında özellikle Türkçe literatürde açıkça görülen eksikliğin giderilmesi ve ilgili literatüre katkı sağlanması amaçlanmıştır. Çalışma kapsamında, politik risk türlerinin, genel istikrarsızlık riski, mülkiyet ve kontrol riski, işletim riski ve transfer risklerinden oluştuğu görülmüş̧ür. Ek olarak, politik risk değerlendirmelerinin temelde, işletme ile ilgili sorunların değerlendirilmesi, olası politik olayların değerlendirilmesi ile muhtemel etki ve tepkilerin değerlendirilmesi olmak üzere üç basamakta gerçekleştiği tespit edilmiştir. Politik risk yönetiminde ise entegre stratejiler, korumac1/savunmacı stratejiler ve kombinasyon stratejileri ana stratejileri oluşturmuştur. $\mathrm{Bu}$ çerçevede, politik risk sigortası yaptırılması, faaliyetlerin kademeli olarak artırılması, yerel bir işletme ile ortaklık kurulması ve yerel istihdam sağlanması, ev sahibi ülke dinamikleriyle ilişki geliştirilmesi ve yerel finansman sağlanması, faaliyetlerin coğrafi olarak çeşitlendirilerek riskin yayılması ve yasal organlara başvurulmasına ilişkin alt stratejilerin dikkat çektiği görülmüştür.

Anahtar Kelimeler: Uluslararasılaşma, Ev Sahibi Ülke, Politik Risk, Risk Azaltma

\section{Giriş}

Günümüzde birçok işletme, faaliyetlerini kendi ülkelerinin sınırları dışarısına yayarak büyümeye çalışmaktadır. Bu açıdan uluslararasılaşma ile ilgili literatür incelendiğinde, işletmelerin uluslararası pazarlara açıllırken temelde ihracat, franchising, lisans anlaşmaları, ortak girişim ve tamamen sahip olunan bağlı ortaklık olmak üzere beş farklı genişleme yöntemi dikkat çekmekte olup (Costa ve Figueira, 2017: 69), bu süreçte işletmeler ticari, finansal, kültürler arası ve politik risk olmak üzere dört temel risk ile karşılaşabilmektedir (Menipaz ve Menipaz, 2011: 151-152). Bu anlamda, işletmecilik faaliyetleri açısından en olumsuz etkiyi yaratan risk türünü nitelemekte olan politik risk, siyasi ortamda meydana gelen gelişmelerin işletme faaliyetlerini doğrudan veya dolaylı olarak olumlu ya da olumsuz bir şekilde etkilemesi ihtimali olarak değerlendirilmektedir (John ve Lawton, 2018: 848). Farklı bir ifadeyle, Haendel (2018: 14)'in de belirttiği üzere politik risk, faaliyetin gerçekleştirildiği ülkede (ev sahibi ülke) meydana gelebilen risk veya siyasi gelişmelerin, işletme faaliyetlerini ve kârlılığı etkilemesi olarak ifade edilmektedir. Benzer şekilde, Musonera (2008: 2)'ya göre ise ülkelerin çevresel faktörleri doğrultusunda ortaya çıkan politik riskler işletmecilik faaliyetlerinden elde edilen kârın ve yatırımcılara ait varlıkların iş çevresinde meydana gelebilecek olası değişimlerden olumsuz yönde etkilenebilmesini nitelemektedir.

$\mathrm{Bu}$ bağlamda, uluslararası işletmecilik faaliyetlerini yıkıcı yönde etkileyebilme gücü olan politik risk, özellikle yirminci yüzyıldan itibaren tüm dünyada büyük yank1 uyandıran bir kavram olmasına karşın (Sun ve Liu, 2018: 50), Türkiye'de akademik anlamda gerekli ilgiyi görmemiş ve yalnızca birkaç bilimsel çalışmanın haricinde derinlemesine olarak araştırma konusu olmamıştır. Bu çalışmada, işletmelerin uluslararasılaşma sürecinde karşılaşılabilecekleri politik risk olgusunun 
tanımlanması ve risk değerlendirmeleriyle bu yıkıcı risk türünden kaçınılması ya da ilgili risk etmenlerini doğru bir şekilde yöneterek tehditlerin firsata dönüştürülmesiyle risk mitigasyonunun sağlanması doğrultusunda, özellikle Türkçe literatürde net bir şekilde görülen eksikliğin giderilmesi ve politik risk literatürüne katkı sağlanması amaçlanmıştır. Bununla birlikte, çalışmanın, uluslararası işletmecilik faaliyeti gerçekleştiren işletmelerin özellikle yurt dışı faaliyetleri sürecinde karşılaşabilecekleri politik risk türleri, olas1 politik risk durumunda değerlendirme gerçekleştirilmesinin önemi ve politik risklere karşı stratejik yönetim araçlarının uygulanmasına ilişkin işletmelere yol gösterici olması beklenmektedir.

\section{Kavramsal çerçeve}

\section{Uluslararası İşletmecilikte Politik Risk}

Ülke sınırları içerisinde faaliyet gösteren ulusal işletmeler, iç piyasa koşullarının yetersiz olması, yalnızca ana ülkede gerçekleştirilen üretimin akılcı işletmecilik uygulamalarına olanak sağlamaması, ev sahibi ülkede iş yapma kolaylığ (ease of doing business) gibi ev sahibi ülkenin çekici faktörlerine ek olarak artan rekabet koşulları doğrultusunda uluslararasılaşarak yabancı pazarlara giriş yapmaktadır. Bu anlamda, işletme faaliyetlerinin birden fazla ülkede gerçekleştiriliyor olması, ona uluslararası işletme niteliğini kazandırmaktadır. Farklı bir ifadeyle, uluslararası işletmeciliğin temel noktası, faaliyetlerin yerel sınırların dışında, birden fazla yabancı ülkede gerçekleşmesidir (Can, 2012: 8). Bu bağlamda, işletmelerin uluslararası pazarlara açılırken temelde ihracat, franchising, lisans anlaşmaları, ortak girişim ve tamamen sahip olunan bağlı ortaklık olmak üzere beş farklı genişleme yöntemine başvurabildiğine dikkat çekilmektedir (Dess ve Miller, 1996: 300; Costa ve Figueira, 2017: 69). Bu süreçte işletmeler, uluslararası anlamda politik ve yasal, finansal ve ekonomik, sosyo-kültürel unsurlar gibi çevresel faktörlere maruz kalmakta (ZembriMary, 2019: 14) ve içerisinde en çarpıcı etkiye sahip olan politik risklerin de bulunduğu birçok risk etmeniyle karşılaşmaktadır (Hernández Gutiérrez, 2018: 1).

$\mathrm{Bu}$ noktadan hareketle Root (1972: 355) politik riski, faaliyetlerin gerçekleştirilmesi sürecinde gerek ana ülkede gerekse ev sahibi ülkelerde gerçekleşme ihtimali olan darbe, devrim, savaş, ayrımcı vergilendirmeler, kamulaştırma ve kısıtlamalar gibi siyasi gelişmelerin, işletme açısından kârlılık veya varlık kaybına neden olabilecek gelişmeler olarak tanımlamaktadır. Farklı bir ifadeyle, varlıkların, güç kazanımının veya yönetimsel kontrolün, ev sahibi ülkede yer alan politik temelli olaylar sebebiyle kaybedilmesi riskini ifade etmektedir (Daft, 2010: 104). John ve Lawton (2018: 848) ise politik riskleri siyasi ortamdaki belirli bir eylem veya eylemsizliğin, doğrudan ya da dolaylı olarak, düzenli veya epizodik bir şekilde işletmelerin makro ve mikro düzeydeki ekonomik çıktılarında olumsuz veya olumlu değişikliklere yol açma olasıllı̆ı olarak nitelemektedir.

Yanı sıra, Loikas (2003: 62)'ın da belirttiği üzere politik risk, siyasi otoriteler ile ekonomik aktörlerin birbirleriyle olan ilişkisinden ortaya çıkmakla birlikte, siyasi, sosyal ve ekonomik çevrede meydana gelen değişimlerin yarattı̆̆ belirsizlikler, iş iklimini olumsuz yönde etkilemektedir. Buradan hareketle, uluslararası işletmecilik faaliyetlerinde politik risk etkisini ele alan ve ilgili literatürün oluşmasına önemli katkı sağlayarak ön plana çıkan araştırmacılara ait tanımları içermekte olan Tablo 1'e aşağıda yer verilmiştir. 
Tablo 1. Politik Risk Tanımlamalarına İlişkin Başlıca Araştırmalar

\begin{tabular}{|c|c|c|}
\hline Analist & Politik Risk Tanımı & Anahtar Değişkenler \\
\hline Van Agtmael & $\begin{array}{l}\text { Millileştirme, politik istikrarsılılık ve dış politik } \\
\text { değişikliklere ilişkin kayıplar }\end{array}$ & $\begin{array}{l}\text { Darbe, savaş, millileştirme, dış politik } \\
\text { değişiklikler }\end{array}$ \\
\hline Green & $\begin{array}{l}\text { Radikal politik değişimler sebebiyle yabancı } \\
\text { işletmelere olumsuz bakış }\end{array}$ & Siyasal sistem türleri \\
\hline Root & $\begin{array}{l}\text { İşçi sendikaları ve milliyetçi gruplar, karşıt } \\
\text { görüşlü siyasi partiler ve ev sahibi ülke } \\
\text { hükümetlerinin tutum ve politikaları }\end{array}$ & $\begin{array}{l}\text { İthalat kısıtlamaları, kamulaştırma, savaş, } \\
\text { mülkiyet/belirsizlik kontrolü, transfer } \\
\text { işlemleri }\end{array}$ \\
\hline $\begin{array}{l}\text { Boddewyn ve } \\
\text { Cracco }\end{array}$ & $\begin{array}{l}\text { Sosyo-ekonomik kalkınmayı teşvik ve kontrol } \\
\text { eden, ev sahibi ülke hükümeti tarafından } \\
\text { uygulanan milliyetçi politikalar }\end{array}$ & $\begin{array}{l}\text { Ulusal egemenlik, ulusal kimlik ve ulusal } \\
\text { çıarlar, }\end{array}$ \\
\hline Stobaugh & Ev sahibi ülkede iş iklimini etkileyen genel şartlar & Devalüasyon, enflasyon ve kamulaştırma \\
\hline Knudsen & $\begin{array}{l}\text { Yabancı işletmelere duyulan rahatsızlık } \\
\text { doğrultusunda işletmelerin kamulaştırılması }\end{array}$ & $\begin{array}{l}\text { Kentleşme ve sendikalaşma derecesi, çevresel } \\
\text { değişkenler, GSYH'de değişim yüzdesi }\end{array}$ \\
\hline Robock & $\begin{array}{l}\text { Siyasi değişikliklerden kaynaklanan, işletmelerin } \\
\text { kâr ve amaçlarını etkileyen, işletme çevresinde } \\
\text { meydana gelebilecek tahmin edilemeyen } \\
\text { aksaklıklar }\end{array}$ & $\begin{array}{l}\text { El koyma, çatışan siyasi görüşler, } \\
\text { kamulaştırma, ayrımc1 vergilendirme ile } \\
\text { kargaşa ve toplumsal huzursuzluk }\end{array}$ \\
\hline Kobrin & $\begin{array}{l}\text { Ev sahibi hükümetlerin yabancı işletmelere } \\
\text { yönelik politikalarındaki önemli değişiklikler }\end{array}$ & $\begin{array}{l}\text { Para transferinin kısıtlanması, fiyat } \\
\text { kontrolleri, kamulaştırma, kısmi el koyma }\end{array}$ \\
\hline
\end{tabular}

Kaynak: Simon (1982: 64)'dan uyarlanmıştır.

\section{Politik Risk Türleri}

Czinkota ve Ronkainen (2013: 142), uluslararası işletmecilikte, temel olarak üç farklı politik risk türü olduğuna dikkat çekmektedir. Bu çerçevede, işletmenin sahip olduğu mülkiyet ile ilgili riskleri niteleyen mülkiyet riski; faaliyetlere gerçekleşebilecek müdahaleleri belirtmekte olan işletim riski ve ülkeler arasındaki fon transferleri ile ilgili riskleri içeren transfer riski, politik risk türleri arasında yer almaktadır. Root (1987: 130-131) ise, politik riskleri genel istikrarsızlık riski, mülkiyet riski, işletim riski ve transfer riski olmak üzere dört temel başlık altında sınıflandırmıştır. $\mathrm{Bu}$ kapsamda, literatürde yer almakta olan dört temel politik risk türü Şekil 1'de yer almaktadır. 


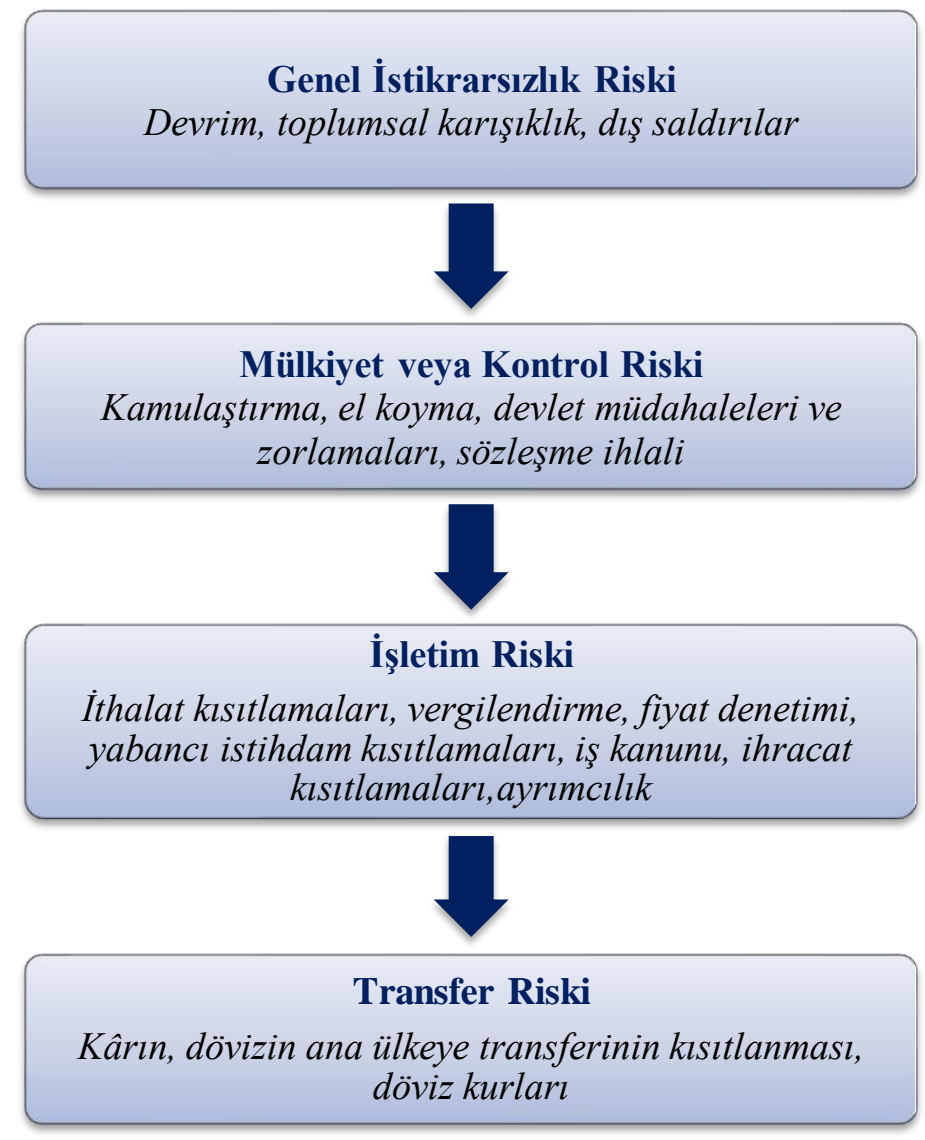

Şekil 1. Politik Risk Türleri

Kaynak: Root (1987: 132)'tan uyarlanmıştır.

\section{Genel İstikrarsızlık Riski}

Simon (1984: 128-129)'a göre genel istikrarsızlık riski, siyasi ortam riskini de kapsamakta olup; hükümetlerin sik olarak değişmesi, grev, boykot, ayaklanma ve gruplar arasında meydana gelebilen çatışmalar doğrultusunda ortaya çıkan politik istikrarsılılılar veya rejim değişiklikleri gibi riskleri içermektedir. Root (1987: 130-131)'a göre genel istikrarsızlık riski ise, ev sahibi ülkedeki siyasi sistemin gelecekte yaşamını sürdürebilmesi ile ilgili ortaya çıkan belirsizlikten meydana gelmektedir.

Bu bağlamda, bir ülkede hükümetin değişmesi ile siyasal sistem de değişebilmekte, normal seçim sürecinde isyan, devrim, ayaklanma ve liderlik mücadeleleri gibi kritik olumsuz durumlar ortaya çıkabilmektedir. Politik istikrarsızlıklar; yoksulluğun, zayıf yönetişimin, gücü kötüye kullanan veya güçsüz ve yetersiz hükümetlerin olduğu ülkelerde daha çok meydana gelmektedir. Bu durum, büyük oranda dişarıdan ekonomik, askeri ve politik desteğe bağımlı olan ülkelerde daha da şiddetli olmaktadır. 1979 yılında meydana gelen İran Devrim'nde Şah'ın ve 2013'te Mısır'da Cumhurbaşkanı Mursi'nin devrilmesi sonucu ortaya çıkan olaylar, genel istikrarsızlık risklerine örnek olarak gösterilebilmektedir.

\section{Mülkiyet Riski}

Mülkiyet riski, hükümetlerin, işletmeleri kontrolü altına alması veya mülkiyet kaybına sebep olabilecek faaliyetlerde bulunması ihtimalinden kaynaklanmaktadır. Bu bağlamda millileştirme, 
kamulaştırma ve el koyma gibi riskler ortaya çıkmaktadır (Root, 1987: 130-131). Diğer bir deyişle, işletmelerin gerçekleştirdiği yatırım sonrasında elde ettikleri varlıklara ilişkin meydana gelebilecek risklerden kaynaklı, varlıkların üzerindeki sahipliğin yüzdelik değişime uğrama riskini kapsamaktadır. Kısaca ifade etmek gerekirse, mal sahipliğinin beraberinde getirdiği riskleri ifade etmektedir. Örnek olarak, 1973 yılında, Hindistan'da döviz yönetmeliği yasalaştığında, yabancı işletmelerin paylarının \%40'a kadar azaltılması zorunlu hale gelmiş ve çoğu işletme, yasanın hükümlerini yerine getiremediğinden tasfiye edilmiş veya işletmelerini yerli işletmelere satmak durumunda kalmıştır (Goyal ve Goyal, 2011: 78).

\section{Transfer Riski}

Transfer riskine, yabancı ülkelerde iştirakleri bulunan ya da aynı ülkede veya yabancı ülkede bağlı kuruluşları olan bilhassa çok uluslu işletmeler (ÇUİ) maruz kalabilmektedir. Bu tür riskler, hükümetlerin hem aynı ülkede hem de yurt dışında ana şirket ve bağlı kuruluşları arasında gerçekleştirdiği işlemleri, hâsılat veya kârın transferini, fon ya da varlıklarını etkileyebilecek olası faaliyetlerden ortaya çıkabilmektedir (Root, 1987: 130-131). Baas (2010: 139)'a göre, transfer riski, yabancı işletmenin, yatırım sermayesini kâr payının veya çıkarların yasal yollarla ana ülkeye geri gönderememesini nitelemektedir. Correia, Poblacion ve Restrepo (2012: 9) ise transfer riskini oluşturan iki temel noktayı vurgulamıştır. Bunlardan en yaygın olanı ve birincisi, hükümetin temerrüde düşmesidir. Bu açıdan hükümet, borçlarını ödeyemeyecek durumda olmaktadır. İkincisi ise, sermaye kontrolleridir. Bu kapsamda, para birimindeki devalüasyon planları ve para transferinin engellenmesi, en sık karşılaşılan transfer riski örneklerinden olabilmektedir.

\section{İşletim Riski}

İşletim riski, işletmelerin pazarlama, insan kaynakları yönetimi, finans, üretim ya da uluslararası işletmecilik faaliyetlerinin hükümetler tarafindan kısıtlanması ihtimali doğrultusunda meydana gelmektedir. Bu durum, belirli işletmelere karşı, yeni bir yasa, politik ya da ekonomik şartların yerine getirilmesi zorunluluğu veya belirli disiplin tedbirleri sonucunda ortaya çıabilmektedir (Root, 1987: 130-131). Correia vd. (2012: 7)'ye göre ise işletim riski, belirsizlikler ve işletmelerin faaliyetlerinin doğrudan kısıtlanması gibi eylemleri belirtmektedir. Bu tanım çok geniş olmasına rağmen, işletim riski genellikle, işletme faaliyetlerinin etkilenmesine sebep olabilecek, politikalar ve hükümetlerin düzenlemeleri ile ilgili olup, mülkiyet ve varlık kaybı anlamına gelmemektedir. Düzenlemelerde oluşabilen değişiklikler, işletmelerin kârlllıklarına etki etmektedir. Bu anlamda, işletim risklerinde en çok karşılaşılan örnekler genellikle vergilendirmeye ilişkin değişiklikler olabilmektedir. Bu çerçevede işletim riskleriyle politik ya da ekonomik sebepler doğrultusunda karşılaşabilmektedir.

\section{Politik Risk Değerlendirmesi}

Risk değerlendirmesi gerek yatırım kararları gerekse politik risk analizinde geçmişten günümüze merkezi rol oynamıştır. Geçmişte, politik risk değerlendirmesine ilişkin yüzeysel çalışmalar gerçekleştirilirken, politik riskin analiz edilmesindeki önem, 1970'li yılları takiben artmış ve bu bağlamdaki bilimsel çalışmalar daha ileri bir boyuta taşınmıştır. Yanı sıra, politik riskin sahip olduğu önemin artması sebebiyle işletmeler, kendi içerisinde risk birimleri kurma eğiliminde olmuştur. Bu çerçevede, politik risk değerlendirmesinin ana amacının, beklentilerin olumsuz yönde etkilenmesine neden olabilecek gelişmelerin gerçekleşmesi olasılığına karşın gerek duyulan, karar almayı kolaylaştıracak bilgilerin elde edilmesi olduğu ifade edilmektedir (Karabay, 1997: 33-35).

Collinson vd. (2006: 373) politik risk değerlendirmesini, ticaret dış1 politik olayların belirli bir pazarda faaliyette bulunan işletmelerin finansal, stratejik ve istihdama dayalı kayba yol açması ihtimaline karş1 yapılan analizler olarak tanımlamıştır. Robock (1971: 10), politik risk tahmini gerçekleştiren uzmanların, belirli sektörlerin maruz kaldığı politik risklerin kaynaklarının belirlenmesi, değerlendirilmesi ve köklü değişimlerin mantığını anlayabilmek adına yalnızca o anın 
resmine bakmaktan fazlasını yapması ve devam eden olayları zamana yayarak analiz etmesi gerektiğine dikkat çekmiştir. Buradan hareketle literatürde politik risk değerlendirmesinde işletme ile ilgili sorunların değerlendirilmesi, olası politik olayların değerlendirilmesi ile muhtemel etki ve tepkilerin değerlendirilmesi (Bkz. Şekil 2) olmak üzere üç temel basamağın bulunduğu dikkat çekmektedir (Hollensen, 2007: 195).

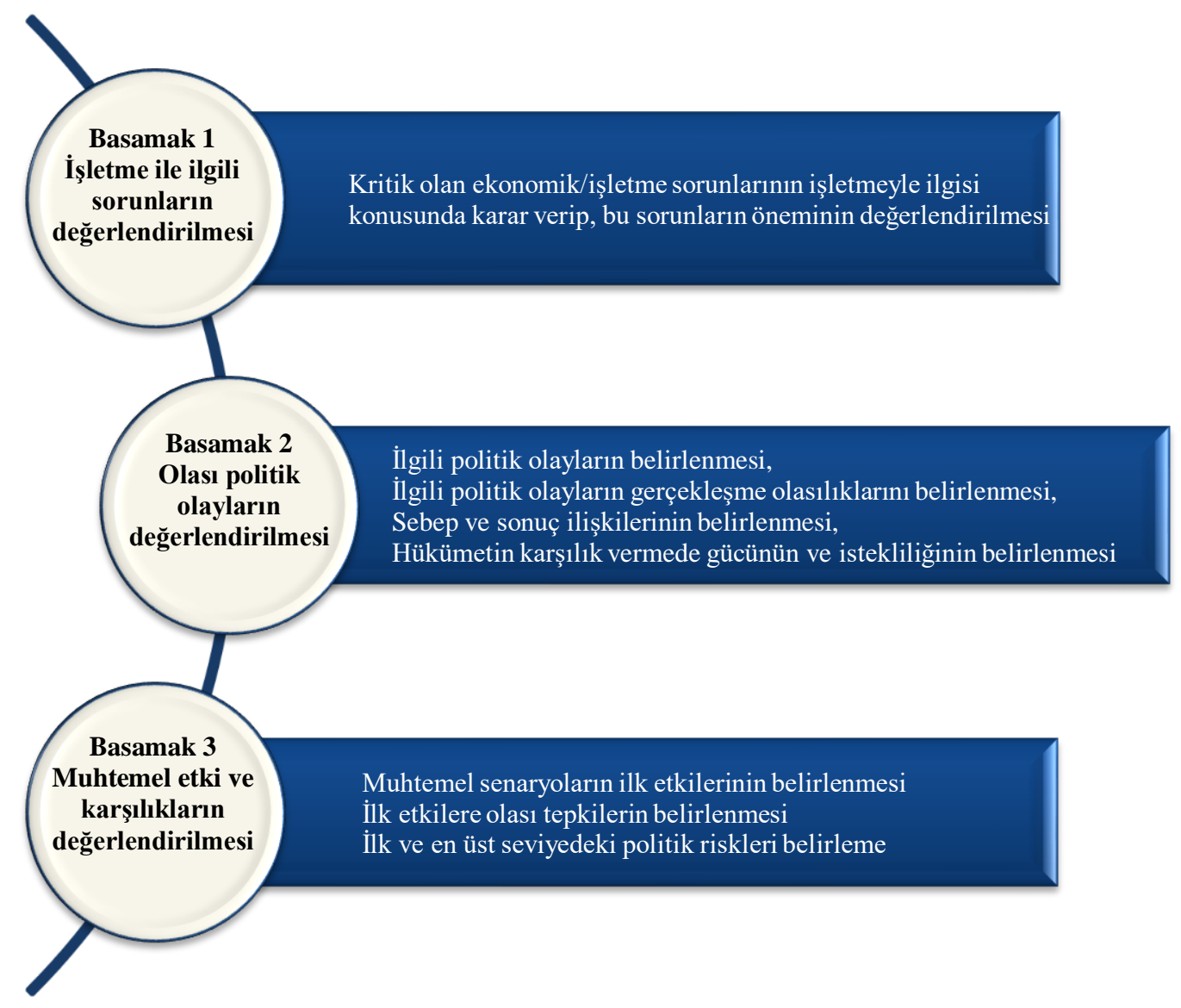

Şekil 2. Politik Risk Analiz Süreci

Kaynak: Hollensen (2007: 195)'den uyarlanmıştır.

İşletme ile ilgili sorunların değerlendirilmesi: Olası problem alanlarının öneminin derecesi ve bu problemlerin işletmeyle ilgisi, aynı ülke içerisinde olsalar dahi işletmeler arasında büyük oranda değişiklik göstermektedir. Bir işletme için, elde edilmiş olan kârın ana ülkeye transferi (ilgili konuyu etkileyecek politikalar ve değişiklikler) en önemli konu olabilmekteyken, aynı ülkede faaliyet gösteren bir başka işletme için ise kârın ana ülkeye transferi daha az kaygı duyulan bir sorun olabilmekte ve ürün kalitesi (işgücü, hammadde ve teknolojiyi etkileyebilecek politika ve değişiklikler) daha çok kaygı duyulan bir konu olabilmektedir (Hollensen, 2007: 195). Bu bağlamda, Robock (1971: 10)'un da vurguladığı üzere, işletme çevresinde, doğrudan seçilmiş belirli bir faaliyet alanında meydana gelen mikro ölçekte politik riskler ortaya çıkabilmektedir. Diğer bir deyişle, aynı ülke içerisinde olunmasına karşın, belirli projelerin çeşitli özellikleri, karşılaşılabilecek politik risk faktörleri ve bunlardan etkilenme olasılığında farklılık meydana gelebilmekte ve bu anlamda mikro politik risklerle karşılaşılma ihtimali gündeme gelebilmektedir.

Olası politik olayların değerlendirilmesi: Politik istikrarsızlıklar genel olarak ekonomik bunalım durumlarında görülebilmektedir. Fakat, hükümetlerin ekonomik durgunlukları kontrol etme 
ve bu olumsuz durumların üstesinden gelmedeki isteği ve kararlılığının kuvvetli olması, yabancı işletmelere doğrudan etkisini de önemli ölçüde azaltabilecektir. Sadece belirli bir politik olayın gerçekleşme ihtimalinin tahmini değil, aynı zamanda ilgili olayların nasıl bir akış içerisinde gerçekleştiği de önem arz etmektedir (Hollensen, 2007: 195). Örnek olarak, "faaliyet gösterilen ev sahibi ülkedeki hükümet değiş̧ikliği, kârın ana ülkeye transferine ilişkin politikaları veya ihracat ve diğer ilgili konuları değişikliğe uğratabilir mi?” gibi sorulara cevap aranmaktadır.

Muhtemel etki ve tepkilerin değerlendirilmesi: Bu basamak, belirli bir işletme için politik riskin gerçek anlamda değerlendirildiği aşama olmaktadır. Ev sahibi ülkede meydana gelen politik riskler nedeniyle gerek aynı endüstrideki farklı işletmeler gerekse farklı endüstrilerdeki işletmeler farklı düzeyde politik risklere maruz kalabilmektedir (Hollensen, 2007: 196). Böylelikle, işletmeye ve endüstriye özgü durumlar sebebiyle, politik riskin de farklı düzeyde etki göstermesi gündeme gelebilecektir.

\section{Politik Risk Yönetimi}

Uluslararası işletmecilik bağlamında ortaya koyulan işletme stratejileri, kuşkusuz politik risk faktörlerinin artış veya azalışı ile etkilenmektedir. Bu anlamda, işletmeler gerek faaliyetler öncesinde gerekse faaliyetler sonrasında maruz kalınan bazı politik risk unsurlarını takiben yararlandıkları doğru politik risk stratejileri sayesinde olası zararları en aza indirgemesi veya bu durumu bir firsata çevirme olanağına erişebilmektedir. Ek olarak, yatırımların gerçekleştirilmesinden önce yatırımdan kaçınma, sigortalama; yatırımların sonrasında riski kontrol altında tutma, transfer etme ve yerel kaynaklardan faydalanma gibi bir dizi strateji oluşturularak uygulanabilmektedir. Politik riskler eğer hükümet kaynaklı bir olumsuz etken olarak ortaya çıktıysa, hükümetle müzakere sürecine başlanabilmekte (Collinson vd., 2006: 386) ve bu doğrultuda hükümet tarafindan alınan kararları 1lımlı hale getirme, yasal hak arama ve ilişki geliştirme gibi birçok aksiyonda bulunulabilmektedir. Robock (1971: 7) ise, politik riskin kaynaklarının Tablo 2'de yer aldığı üzere önemli sonuçlar yaratabileceğini ifade etmiştir. Bu sebeple, yöneticilerin muhtemel risk ve sonuçlarını göz önünde bulundurarak buna göre eylemde bulunması gerekli olmaktadır. İşletmelerin tanımlaması gereken ilgili birçok etken ve muhtemel etkileri, bu risklerin yönetilmesinde merkezi rol oynamaktadır.

Tablo 2. Politik Risk Kaynakları, Etki Eden Gruplar ve Etkileri

\begin{tabular}{|c|c|c|}
\hline Politik Risk Kaynakları & $\begin{array}{l}\text { Politik Riske Sebep Olabilecek } \\
\text { Gruplar }\end{array}$ & Politik Riskin Etkileri \\
\hline $\begin{array}{ll}\text { - } & \text { Değişen veya çekişen siyasi } \\
& \text { ideolojiler } \\
\text { - } & \text { Değişen ekonomik şartlar } \\
\text { - } & \text { Toplumsal huzursuzluk } \\
\text { - } & \text { Artan milliyetçilik } \\
\text { - } & \text { Siyasi bağımsılıklar } \\
\text { - } & \text { Yerel işletme gruplarının } \\
& \text { çıarları } \\
\text { - CCekişen dini gruplar } \\
\text { - } \quad \text { Rekabet } \\
\text { - } \quad \text { Yeni oluşmuş uluslararası } \\
\quad \text { ittifaklar }\end{array}$ & $\begin{array}{ll}\text { - } & \text { Mevcut hükümet ve çeşitli } \\
\text { kurumları } \\
\text { - } \\
\text { Hükümet içerisinde, iktidarda } \\
\text { olmayan fakat siyasi nüfuzu } \\
\text { olan karşıt gruplar } \\
\text { - Örganize çıar grupları } \\
\text { - Ülkede faaliyet gösteren terör ya } \\
\text { da anarşi grupları } \\
\text { BM veya Dünya Bankası gibi } \\
\text { - uluslararası kuruluşlar } \\
\text { Ülkelerle uluslararası ittifaklara } \\
\text { girmiş veya hükümete karşı } \\
\text { gruplara destek veren yabanc1 } \\
\text { hükümetler }\end{array}$ & $\begin{array}{ll}\text { - } & \text { Varlıkların kamulaştırılması } \\
\text { - } & \text { Yerelleşmeye ilişkin } \\
& \text { düzenlemeler } \\
\text { - Özgürce faaliyette } \\
\text { bulunmaya kısıtlamalar } \\
\text { getirilmesi } \\
\text { - Mülkiyete ve/veya bireylere } \\
\text { terör ya da ayaklanma gibi } \\
\text { zarar verilmesi } \\
\text { - Sözleşmelerin revize edilmesi } \\
\text { veya iptal edilmesi } \\
\text { - } \quad \text { Vergilerin artırılması ve diğer } \\
\text { para cezaları } \\
\text { - Finansal özgürlüklerin } \\
\text { kaybedilmesi (kârın ana } \\
\text { ülkeye transferinin } \\
\text { engellenmesi gibi) }\end{array}$ \\
\hline
\end{tabular}

Kaynak: Robock (1971: 7)’tan uyarlanmıştır. 


\section{Politik Risk Yönetimi ve Alternatif Stratejiler}

Politik risk bileşenlerinin etkisini ve şiddetini her geçen gün artırması şüphesiz kaçınılmaz bir şekilde işletme stratejilerini de yakından ilgilendirmektedir. Mckellar (2010: 159), politik risk yönetim stratejisinin, işletmelerin politik risklere ilişkin benzersiz, uzun dönemli yaklaşımı nitelediğinin altını çizmektedir. Bu çerçevede, politik risklerin stratejik açıdan ele alarak her işletmenin kendi amacı ve kendisine özgün kurumsal kültürü doğrultusunda yaklaşımlarını şekillendirmesi, merkezi rol oynamaktadır. Buradan hareketle, Collinson vd. (2006: 394-395)'nin de dikkat çektiği, politik risk etkisinin azaltılması noktasında literatürde yer alan ana ve bazı alt stratejilere aşağıda yer verilmiştir:

- Entegre stratejiler (ev sahibi ülke çevresine uyum sağlamak için, yerel hükümetlerle ilişki geliştirmek, çıkar grupları ile ilişki kurmak vb.)

- Korumacı/savunmacı stratejiler (Ar-Ge faaliyetlerini ev sahibi ülke dışında konumlandırmak, yerel çalışanları istihdam etmek, finansmanı ev sahibi ülkeden sağlamak, operasyonel hedging gibi)

- Kombinasyon stratejileri (hem entegre hem korumaci/savunmaci stratejilerin bir arada kullanılmas1).

$\mathrm{Bu}$ çerçevede entegre stratejiler, ev sahibi ülkenin bir parçası olabilmek adına yöneticilerin sıklıkla tercih ettikleri stratejileri ifade etmektedir. Entegre stratejinin asıl amacı, işletmenin çevreye adapte olabilmek ve yabancı olduğunun daha az farkına varılmasını sağlamaktır. Bu noktada, yabancı işletme çağrışımı yapmayacak ya da bir işletme satınalması yapıldıysa mevcut ismin korunması, katkı sunmaktadır. Örneğin, bir lastik firması olan Bridgestone'un bir Japon firması olduğunu yalnızca ismine bakarak değerlendirmek güç olmaktadır (Collinson vd., 2006: 394).

Diğer taraftan, korumacı ve savunmacı stratejiler, ev sahibi ülke hükümetinin yabancılara ait işletmecilik faaliyetlerine müdahale etmesini engelleyebilmek amacıyla başvurulan stratejileri içermektedir. Entegre stratejilerin aksine, korumacı ve savunmacı tekniklerde, yerel çevreye uyum sağlamak pek tercih edilmemektedir (Aswathappa, 2008: 127). Kombinasyon stratejileri kapsamında ise işletmeler politik riskin azaltılması ve yönetilmesinde sıklıkla entegre ve korumacı/savunmacı tekniklerden oluşan bir kombinasyonun kullanımına başvurmaktadır (Suder, 2009: 97-98).

Benzer şekilde, Robock, Simmonds ve Zwick (1989: 360-372) politik risklerin yönetiminde işletmelere birçok alt stratejiden oluşan üç temel stratejiyi izlemelerini önermektedir (akt. Çilingir, 2004: 82-88):

- Savunma stratejileri (işletme faaliyetlerinde değişikliğe gitmek, faaliyetlerin yerini ve dağılımlarını değiştirmek, maddi olmayan varlıkların kontrolünü muhafaza etmek),

- Başkalarından yardım almak veya başkalarını dâhil etmek (ana ülke desteği sağlamak, yerel işletmeleri teşvik etmek, yerel ortaklıklar geliştirmek, sahipliği yerel işletmelerle paylaşmak),

- Karşıt eylemlerde bulunmak (lobicilik faaliyetleri gerçekleştirmek, pazarlık yapmak, hukuki yollara başvurmak).

Doz ve Prahalad (1980: 151-152)'a göre ise, özellikle politik riskin yıkıcı etkilerinin gerçekleşmesi durumunda bir dizi strateji izlenebilmekte ve böylece işletmeler, faaliyetlerini olumsuz olarak etkileyen unsurlara karşı kendilerini koruyabilmektedir. Bu kapsamda, politik risklerin, bir ülkede meydana geldikten sonra farklı stratejiler uygulanarak meydana gelen olumsuz etkileri azaltılabilmektedir. Bu dört farklı strateji ise aşağıda yer aldığı üzere, "adapte olmak", "geri çekilmek", "geçiçi olarak geri çekilmek" ve "karşılık vermek" olarak ifade edilmektedir. 
Adapte olma stratejisi, olası politik risk karşısında (örneğin; hükümet değişikliği), pazardan tamamen çekilmektense, mevcut duruma karşı uyum sağlama ve pazarda kalma çabalarının devamlılığını ifade etmektedir (Doz ve Prahalad, 1980: 151). Bu çerçevede, risk ihtimali düşmekte ancak riskten etkilenmede değişiklik beklenmemektedir. Bu stratejiye örnek olarak, ev sahibi ülkede yaşayan vatandaşların (yerel halkın) ya da hükümet-hükümet dışı aktörlerin yönetsel kararlara katılım sağlayarak bir "katılımcı yönetim" sergilenmesi verilebilecektir. Farklı bir örnek olarak ise, yabanc1 işletmenin yerel bir işletme gibi algılanmasına ilişkin çaba göstererek faaliyetlerin yerelleştirilmesi ya da yerel tedarik/dış kaynak kullanımı yoluyla yerel kalkınmaya katkı sunulması verilebilmektedir (Beeman ve Taoka, 1991: 240).

İşletme faaliyetlerinin önemli ölçüde zarar görmesi, çalışanların can güvenliğinin tehlikede olabilme ihtimali, ev sahibi ülkede meydana gelen ekonomik ve finansal zorluklar, yerel hükümetlerin yabancı işletmelere karşı olumsuz yöndeki davranışları ve tüm bu hususlar sonucunda da faaliyetlerin artık söz konusu pazarda varlığını devam ettirilemeyeceği düşüncesinden hareketle, işletmenin ilgili pazardan çıkmasına ilişkin vereceği karar ise "geri çekilme" olarak ifade edilmektedir (Doz ve Prahalad, 1980: 151). Özetle, geri çekilme doğrultusunda, yeni bir faaliyet gerçekleştirilmemekte, risk ihtimali ve riskin çarpan etkisi sıfira indirgenmekte ve bu açıdan, kâr ya da para akışı da sıfıra indirgenmiş duruma gelmektedir (Beeman ve Taoka, 1991: 240).

Diğer taraftan, işletmeler, faaliyetlerin askıda kalmasını ifade eden geçici olarak geri çekilme stratejisini, özellikle hükümetlerin ortaya koydukları ekonomi ve kalkınma ile ilgili politikalarda meydana gelen olumsuz yöndeki değişmeler çerçevesinde tercih edebilmektedir. Son olarak ise, adapte olma ve geri çekilme stratejilerinin arasında yer alan karşılık verme stratejisi, işletmelerin faaliyette bulunduğu endüstri/sektörde kaydedeceği uzmanlık doğrultusunda rekabet avantaj1 kazanması ve politik risklere karşı göstereceği direnç yolunu seçmesini ifade etmektedir (Doz ve Prahalad, 1980: 152).

Yanı sıra, Çavuşgil, Knight, Riesenberger, Rammal ve Rose (2008: 182-185), uluslararası işletmecilik faaliyetlerinde karşılaşılan ülke kaynaklı politik, yasal ve ekonomik riskleri yönetebilmek ve yabancı pazarlarda bu açıdan başarılı olabilmek için aşağıda yer alan stratejileri önermektedir:

- Faaliyette bulunacak yabancı ülkenin politik, yasal, ekonomik alanlarda çevresel analizini yapmak ve hesaplanabilir riskleri belirlemek,

- Uluslararası toplum etik ve ahlaki davranış biçimlerinde ödün vermemek ve şeffaf yönetim ilkeleri 1şı̆̆ı altında faaliyette bulunmak,

- Yabancı ülke politik, yasal ve ekonomik çevresel koşullarını iyi bilen deneyimli ve yetkin yabancı ülke yerel işletmeleriyle ortaklık ve iş birlikleri yapmak,

- Uluslararası hukuk sistemi içinde kabul edilebilir, geçerli sözleşmeler ile işletme haklarını teminat altına almak ve korumak.

Bu bağlamda, aşağıda yer alan Şekil 3'te, Çok taraflı Yatırım Garanti Ajansı'nı ifade eden MIGA (2013: 37)'nın hangi politik risk yönetim stratejilerinin daha sık olarak kullanılmakta olduğuna ilişkin 459 ÇUİ üst düzey yöneticisi ile yapmış olduğu araştırma kapsamında ortaya çıkan sonuca yer verilmiştir. Yerel çevre ile yakınlık kurarken yatırımın kademeli olarak artırılması başta olmak üzere en sık kullanılan politik risk yönetim stratejileri, yerel bir işletme ile ortaklık kurmak, ev sahibi ülke hükümeti ile ilişki kurmak, politik ve ekonomik risk analizi ve bölge halkı ile uyum sağlanması noktasında iyi ve etkili ilişkilerin kurulması olmuştur. 


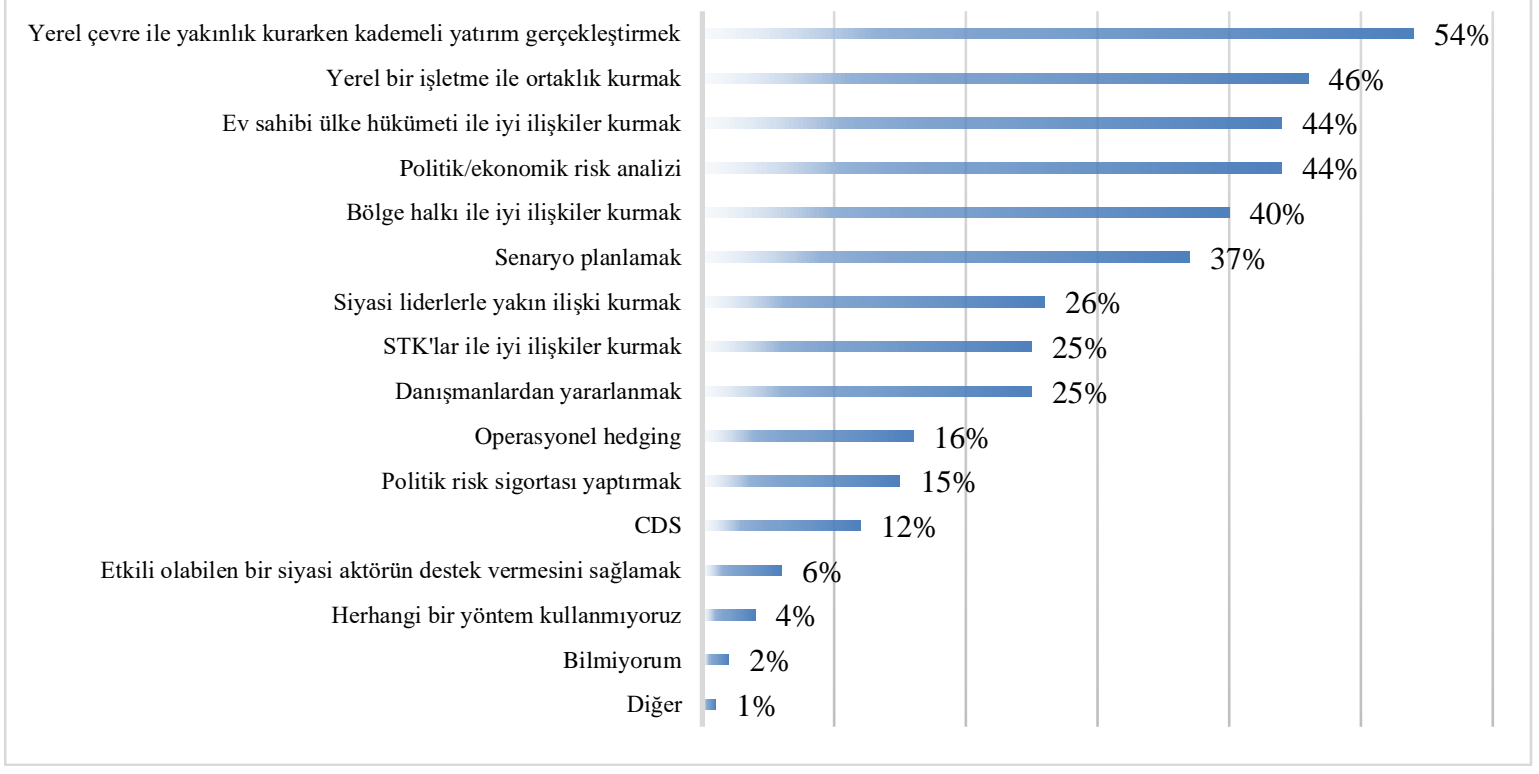

Şekil 3. İşletmelerin Faydalandıkları Politik Risk Mitigasyon Yöntemleri Kaynak: MIGA (2013: 37)'den uyarlanmıştır.

Yukarıda yer alan hususlardan hareketle, literatürde ön plana çıkan ve güncel politik risk araştırmalarında yer alan başlıca alt stratejiler aşağıda incelenmiştir.

\section{Politik Risk Sigortası Yaptırmak}

İşletmelerin, politik riskleri yönetme noktasında başvurdukları yöntemlerden en önemlilerinden birisi de politik risk sigortalarıdır. Farklı bir ifadeyle, uluslararası işletmecilik faaliyetlerinde özellikle yatırımların güvencesinin temini için, sigorta yaptırma seçeneğinin tercih edilmesi önem arz etmekte olup; işletme yöneticilerinin meydana gelebilecek riskler karşısında potansiyel kayıplarının sigorta sağlayıcı kuruluş tarafından üstlenilerek riskin minimum düzeye indirgenmesini ifade etmektedir. Politik risk sigorta sağlayıcıları ise DEİK (2011: 12-13)'in de ifade ettiği üzere ihracat kredi kuruluşları, uluslararası kuruluşlar ve özel sigorta şirketleri olmak üzere üç temel kategori altında toplanabilmektedir:

İhracat Kredi Kuruluşları: Genellikle, kendi ülkelerinin yatırımcı ve ihracatçılarının yurtdışı projelerinin desteklenmesi misyonu kapsamında, yatırımcıların yabancı bir ülkede maruz kalabileceği politik riskleri teminat altına almaktadır. Söz konusu kuruluşlar, ülkelerinin dış politikaları doğrultusunda hareket etmektedir. Türk-Eximbank, bu tür kuruluşlar arasında olup, uluslararası işletmecilik faaliyetlerini desteklemekte ve sigortalamaktadır.

Uluslararası Kuruluşlar: MIGA, Afrika Ticaret Sigortası Ajansı (ATI), ICIEC (İslam Ülkeleri arası Yatırım ve İhracat Kredi Sigortası Kurumu) gibi kuruluşlar, uluslararası ticaret, yatırım ve projelerin gelişimini destekleme misyonunu üstlenmekte ve bu doğrultuda, üye ülkeleri arasında, öncelikle yatırım riskine yönelik olmak üzere politik riskleri sigortalamaktadır (DEIK, 2011: 12). Örneğin, yayınladıkları raporlarla yatırımcılar için danışmanlık hizmetleri sağlayan ve yatırımcıları yönlendiren MIGA, 1998 yılında Dünya Bankası'nın yan kuruluşu olarak faaliyetlerine başlamış olup özellikle gelişmekte olan ülkelere yapılacak doğrudan yabancı yatırımları politik risklerin önemli boyutlarından olan terörizm, savaş, kamulaştırma gibi risklere karşı korumaya çalışmaktadır. $\mathrm{Bu}$ açıdan, uluslararası işletmecilik faaliyetlerinin gelişimine katkı sunduğu dikkat çekmektedir (Günal, 2006: 92). 
Özel Sigorta Pazarı: Özel sigorta piyasaları, geleneksel politik risk teminatlarına ek olarak, gelişmekte olan ülkelere yönelik alacak riski için de teminat sağlamaktadır. Özel sigorta piyasasının kapasitesi yeni oyuncularla beraber artış göstermiştir. Bu noktada, kapasite ve fiyatlandırmada reasürörlerin sigorta şirketlerine sağlayacağı destek de önem taşımakta (DEIK, 2011: 12-13) olup; sirasıyla Swiss Re, Munich Re, Hannover Re, SCOR ile Berkshire Hathaway en güçlü reasürörler arasında yer almaktadır (Best, 2019: 15).

\section{Faaliyetleri Kademeli Olarak Artırmak}

Ev sahibi ülkelerde gerçekleştirilecek uluslararası işletmecilik faaliyetlerinin kademeli olarak artırılması günümüzde işletmelerin faydalanabilecekleri önemli bir seçenek olma niteliği taşımaktadır. Uppsala uluslararasılaşma modeline benzer şekilde, işletmeler, uluslararasılaşma derecelerini aşama aşama artırabilmekte ve böylesine bir stratejiden faydalanmak suretiyle, süreç içerisinde dış çevreyi daha iyi analiz etme ve bunun bir sonucu olarak da deneyimleyebilecekleri risk ve belirsizlikleri de minimize etme firsatını elde edebilmektedir. Bu doğrultuda, Hollensen (2007: 196), faaliyetlerin kademeli olarak artırılması sürecinde ev sahibi ülkenin yabancı işletmeleri benimsemesinin politik riskleri büyük ölçüde azaltacağı hususundan hareketle, yerel halk ile bağ kurma ve onlarla bütünleşme faaliyetleri kapsamında birçok yola başvurabilen uluslararası işletmelerin, yalnızca kâr amacı güden kuruluşlar olarak algılanmaması adına faaliyette bulunulan bölgenin "yerel bir vatandaşı olmak" ve yerel topluma tekrardan "yatırım yapmak" hususlarına ayrıca önem verdiğine dikkat çekmektedir.

\section{Yerel Bir İșletme ile Ortaklık Kurmak ve Yerel İstihdam Sağlamak}

İşletmeler genellikle, ev sahibi ülkelerde yer alan yerel şirketlerle ortak girişimlerde bulunarak politik riski azaltma gayretinde olmaktadır. Böylece, hükümet, yabancı işletmenin faaliyetlerine karşıt bir eylemde bulunması durumunda yerel partnerin de etkileneceğini bilecektedir. Yerel bir ortak, böylesine bir eylemde bulunmayı planlayan hükümet üzerinde kısitlayıcı bir etki yaratmaktadır. Yanı sıra, yabancı işletme adına lobicilik faaliyetlerine de katkı sunarak önemli temaslarda bulunabilmektedir (Ajami, Goddard ve Khambata, 2006: 27).

Diğer taraftan, yabancı işletmeler yerel işletme ile ortaklık kurarken yerel istihdam da sağlayabilmektedir. Politik istikrarsızlık durumlarında bile, işlerindeki devamlılığının tehlikeye girebileceği kaygısıyla yerel çalışanlar, hükümetlerin olası müdahalelerine karşı, istihdam etmekte oldukları yabancı işletmelerini koruyabilmektedir. Bu sebeple, yerel çalışanlar kendi yaşantılarını göz önünde bulundurarak işletmelerinin yaşamını devam ettirebilmeleri adına büyük bir gayret içerisinde olacaktır (Hollensen, 2007: 196). Ancak, Collinson vd. (2006: 394)'nin de ifade ettiği üzere, bazı yabancı işletmeler, faaliyetlerinin yürütülmesinde kritik pozisyona sahip olan stratejik noktalarda yerel çalışanları mümkün olduğunca bulundurmamaktadır. Böylece ev sahibi ülke hükümeti, işletme faaliyetlerine el koyarsa, önemli birimlerde faaliyette bulunmayan yerel çalışanlar sebebiyle, ev sahibi ülke çalışanı da etkili ve verimli bir şekilde faaliyete devam edemeyecektir.

\section{Ev Sahibi Ülke Dinamikleriyle İlişki Geliştirmek ve Yerel Finansman Sağlamak}

Birçok ülkede yasalar hızlı bir şekilde değişmekte ve yenileri yürürlüğe girmekte olduğundan, yöneticiler faaliyette bulunacakları ülkelerin iş çevresi kapsamına giren ilgili tüm kanun ve uygulamaları takip etmektedir. Bu kapsamda işletmeler, ev sahibi ülkedeki işletmecilik faaliyetlerinde siyasetçileri veya sivil toplum kuruluşlarını etkilemek kaydıyla kendilerinin lehine olacak değişiklik tekliflerinde ve lobicilik faaliyetlerinde bulunabilmektedir (Hollensen, 2007: 196). Diğer taraftan, işletmeler, faaliyetlerini gerçekleştirmek için ihtiyaç duydukları finansmanı ev sahibi ülkelerden sağlayabilmektedir. Böylece, ev sahibi ülke hükümetlerinin, yabancı işletmenin faaliyetlerine bir müdahalesi söz konusu olduğunda kendi bankalarına ve kuruluşlarına da zarar geleceğinin de farkında olacaktır. Bu durum ise, ev sahibi ülke hükümetini işletmecilik faaliyetinin 
bir üyesi, bir parçası haline getirecek ve faaliyetlere herhangi bir karşıt eylem gerçekleştirilirse ev sahibi ülke de dolaylı yoldan etkilenecektir (Collinson vd., 2006: 394).

\section{Faaliyetleri Coğrafi Olarak Çeşitlendirerek Riski Yaymak}

Varlıkların ve faaliyetlerin coğrafi olarak çeşitlendirilmesi (operational hedging), işletmelerin yalnızca belirli bir ülkenin hükümeti kaynaklı kararlarına ya da ekonomik durumuna maruz kalmaması (Hub Guides, 2013: 1-4), aynı zamanda riskin bu anlamda azaltılması anlamına da gelmektedir (Austin, 1996: 117). Ayrıca, coğrafi çeşitlendirme ve riskin dağıtılması çerçevesinde, özellikle Ar-Ge faaliyetlerinin ev sahibi ülke dışarısında konumlandırılması ve gerekli oldukça bu strateji ile bilgilerin ilgili ülkeden ithal edilmesi de söz konusu olabilmektedir. Böylece, ev sahibi ülke hükümetinin, işletmenin varlıklarına el koyması halinde, işletmelerin sürdürülebilirliği noktasında hayati öneme sahip Ar-Ge faaliyetlerine zarar gelmeyecektir (Collinson vd., 2006: 394).

\section{Yasal Organlara Başvurmak}

Ev sahibi ülkede uluslararası işletmecilik faaliyetleri gerçekleştirilirken özellikle hükümet müdahalelerinin bir sonucu olarak işletme tarafindan deneyimlenen olumsuz durum ve kayıplar doğrultusunda faydalanılabilen bir strateji olan yasal organlara başvurma ile ilgili olarak üç temel basamak bulunmaktadır. Bu basamaklar "Şekil 4"te yer aldığı üzere uzlaşma, tahkim ve litigasyonu (ticari anlaşmazlıkların dava açma yoluyla çözümlenmeye çalışılması) içermektedir. Arayol bulma olarak da bilinen uzlaşma kapsamında üçüncü kişiler, taraflar ile anlaşma sağlayarak problem alanının çözülmesine katkı sunmaya çalışmaktadır. Uzlaşılamama durumunda ise, tahkim önemli bir opsiyon olmaktadır. Litigasyon'dan bir önceki aşama olan tahkim, litigasyon yerine işletmelerin ticari anlaşmazlıklarda en sık olarak başvurdukları yöntem olarak görülmektedir (Aswathappa, 2008: 133-135).

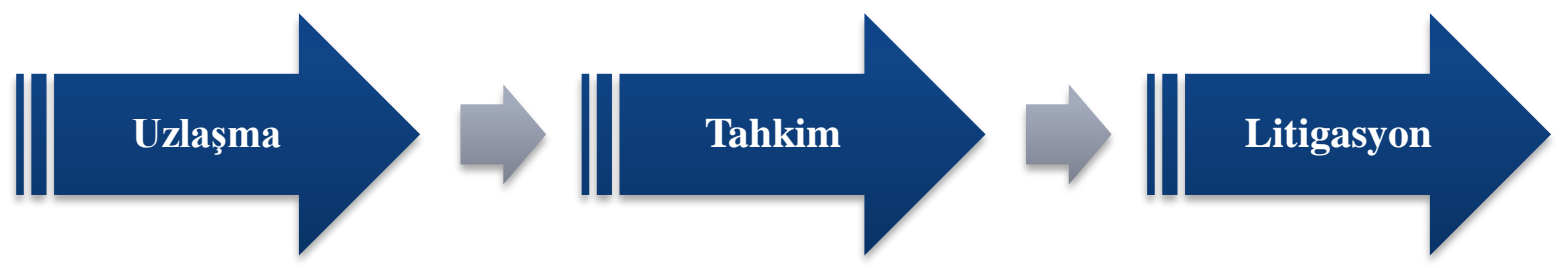

Şekil 4. Politik Riskin Ortaya Çıkması Halinde Başvurulan Yasal Süreç Aşamaları Kaynak: Aswathappa (2008: 134)'dan uyarlanmıştır.

Diğer taraftan, 14 Ekim 1966 tarihinde yürürlüğe girmiş olan "Devletler ve Diğer Devletlerin Uyrukları arasındaki Yatırım Anlaşmazlıklarının Çözümü için Sözleşme (Convention on the Settlement of Investment Disputes Between States and Nationals of Other States)" esaslar1 çerçevesinde kurulmuş olan ve 163 ülke tarafindan imzalanmış, 154 ülkenin ise güncel olarak uygulamakta olduğu (https://icsid.worldbank.org, Erişim Tarihi: 02.01.2020)

Uluslararası Yatırım Anlaşmazlıklarının Çözüm Merkezi (ICSID) büyük önem taşımaktadır. $\mathrm{Bu}$ önemin sebebi ise, ICSID'in uluslararası yatırım akışının korunabilmesi için hükümetlerle yabancı özel yatırımcılar arasındaki anlaşmazlıklarda doğrudan başvuru yapılabildiği, arabuluculuk ve tahkim imkânlarının sunulduğu bir oluşumu teşkil etmesidir. Buradaki temel düşünce, anlaşmazlık durumunda başvurulabilecek tarafsız ve güvenilir bir kurum aracılığıyla, küresel yatırım ortamının pürüzsüz işlemesine, problem alanlarının süratle ortadan kaldırılabilmesine ve uluslararası yatırım akışında artış sağlanmasına katkıda bulunulmasıdır (www.mfa.gov.tr, Erişim Tarihi: 03.01.2020).

Bununla birlikte, sadece yabancı işletmeler değil aynı zamanda yerel işletmeler de bu önemli enstrümanı kullanabilmektedir. Örneğin; Rusya'da, 2004 yılının en zengin iş insanı seçilen Mikhail 
Hodorkovski'nin, 1990'larda devlet varlıklarının özelleştirilmesiyle sahip olduğu petrol devi Yukos'un da bağlı olduğu organizasyon olan GML Group'a, geçmişte 27 milyar dolarlık vergi cezası kesilmiştir. Kesilen vergi cezasına ek olarak grubun tüm aktiflerini dondurma kararı alınmıştır. Takip eden yıllarda ise grup, ticari faaliyetlerini durdurma kararı alındığı için bahse konu tutarı ödeyememiş ve beklendiği şekilde iflasını ilan etmiştir. Grubun, Sibirya'da bulunan petrol yataklarının da içerisinde bulunduğu varlıkları Rosneft'e, gaz rezervleri de Gazprom'a satılmıştır. Akabinde, grubun yönetim kadrosu, 2005 y1linda hem yerel hem de uluslararası mahkemelerde maruz kaldıkları söz konusu kamulaştırma kararına karşı hukuki yollara başvurmuştur (www.hurriyet.com.tr, Erişim Tarihi: 02.01.2020). Uzun yıllar süren bu hukuki süreçte ise Lahey Uluslararası Tahkim Mahkemesi, Rus hükümetinin politik sebepler doğrultusunda el koymasına ilişkin kararın usule uygun olmadığına hükmederek Rusya'yı 50 milyar dolar tazminat ödemeye mahkûm etmekle birlikte, Belçika ve Fransa'da bulunan Rusya'ya ait varlıklara el konulduğunu açıklamıştır (www.ntv.com.tr, Erişim Tarihi: 04.01.2020).

\section{Sonuç ve Öneriler}

Ulusal düzeyde faaliyetlerini gerçekleştiren işletmeler, iç piyasa koşullarının yetersiz olması, yalnızca ana ülkede gerçekleştirilen üretimin akılcı işletmecilik faaliyetlerine olanak sağlamaması, ev sahibi ülkede iş yapma kolaylığı (ease of doing business) gibi ev sahibi ülkenin çekici faktörlerine ilave olarak artan küresel rekabet koşulları doğrultusunda uluslararasılaşarak yabancı pazarlara giriş̧ yapmaktadır. Uluslararası anlamda faaliyet göstermek ise, çok daha zorlu çevresel koşulları içerisinde barındırmakta olup; böylesine bir çevre içerisinde işletmeler ticari, finansal, kültürler arası ve politik risk olmak üzere dört temel risk ile karş1laşabilmektedir (Menipaz ve Menipaz, 2011: 151152). Ev sahibi ülke hükümeti kaynaklı uygulamalar, hükümet politikaları, istikrarsızlık, terörizm gibi unsurların, uluslararası işletmecilik mantığını çok farklı bir istikamete taşıyacak potansiyele sahip olması sebebiyle politik risklerin işletmeler üzerinde, gelecekte de sahip olduğu yıkıcı etkiyi sürdüreceği dikkat çekmektedir. Bu açıdan işletmeler, hedef ülkelerde pazara giriş yöntemine (temelde ihracat, franchising, lisans anlaşmaları, ortak girişim ve tamamen sahip olunan bağlı ortaklık) ilişkin kararı ev sahibi ülke risk düzeyine göre şekillendirmeye devam edecektir.

Politik riskin, bu şekilde çok boyutlu hale gelmesinin arka planında yer alan neden, riskin bu bileşeninin global gelişmelerle amorflaşması, yani ölçülmesi güç, adeta şekilsiz bir olgu haline dönüşmesidir. Eski, olguyu tanımlayamayan, riski karşılayamayan bir politik risk algılama yaklaşımının bu çok boyutluluk karşısında yetersiz kalacağı aşikârdır. Farklı bir ifadeyle, öngörülemez bir gelecek inşasının imkânsızlığından hareketle, işletmelerin öncelikli olarak, politik riskin y1kıcı etkisine karşı proaktif davranarak bir dizi önlem geliştirmesi zorunluluk haline gelecektir. Bu ise ancak riskin doğru bir şekilde tanımlanması, faaliyet öncesi ve faaliyet sonrası rutin olarak değerlendirilmesi ve etkili bir şekilde yönetimi ile mümkün olacaktır. Böylesine bir yaklaşımın benimsenmesi ise, yüksek risklerin ve anlık olarak meydana gelebilecek değişimlerin çarpan etkisiyle önemli fırsatların ortaya çıkması durumunda tehditlerin firsata dönüştürülmesi veya risk mitigasyonunu sağlayabilecektir. Nitekim, riski sadece ölçmek tek başına yeterli olmayacak riskin aynı zamanda doğru stratejik araçlara başvurularak yönetilmesi de önem taşıyacaktır.

Buradan hareketle, temel olarak, genel istikrarsızlık riski, mülkiyet ve kontrol riski, işletim riski ve transfer risk türlerinden oluşan politik risklere karşı farkındalığın yüksek ve daha dikkatli olunması; bu dört temel politik risk bağlamında işletme ile ilgili sorunların, olası politik olayların ve muhtemel etki ve tepkilerin aşama aşama ve derinlemesine olarak değerlendirilmesi, uluslararası işletmelere önerilmektedir. Bu değerlendirmeler doğrultusunda, politik risk sigortası yaptırmak, faaliyetleri kademeli olarak artırmak, yerel bir işletme ile ortaklık kurmak ve yerel istihdam sağlamak, ev sahibi ülke dinamikleriyle ilişki geliştirmek ve yerel finansman sağlamak, faaliyetleri coğrafi olarak çeşitlendirerek riski yaymak, yasal organlara başvurmak gibi bir dizi entegre ve korumacı stratejiden faydalanarak, hem entegre hem korumac1/savunmac1 stratejilerin bir arada 
kullanılmasının önem arz ettiği durumlarda kombinasyon stratejilerine başvurulması tavsiye edilmektedir. Politik riskin yıkıcı etkilerinin gerçekleşmesi durumunda ise adapte olma, geri çekilme, geçici olarak geri çekilme ve karşılık verme stratejilerine başvurulması önerilmektedir. Böylece, bu çalışmanın, hedef pazarların seçimi ve işletmelerin uluslararası düzeydeki faaliyetlerinin gerçekleştirilmesi sürecinde karşılaşabilecek politik risk türlerinin tanımlanması, olası politik risk durumunda değerlendirme gerçekleştirilmesinin önemi ve politik risklere karş1 stratejik yönetim araçlarının etkili bir şekilde uygulanmaya konulmasına ilişkin işletmelere rehberlik etmesi ve yol gösterici olması beklenmektedir. Diğer taraftan, gelecekte politik risk ile ilgili özellikle Türkçe alanyazında açıkça görülen eksikliğin giderilmesine yönelik kavramsal çalışmaların artırılmasına ek olarak sektörel düzeyde bu risklerin incelenmesi, özellikle uygulamaya yönelik nitel ve nicel çalışmaların gerçekleştirilmesi araştırmacılara önerilmektedir.

\section{Kaynakça}

Ajami, R. A., Cool, K., Goddard, G. J., \& Khambata, D. (2006). International business: Theory and practice. USA: ME Sharpe.

Aswathappa, A. (2008). International business. New Delhi: Tata McGraw-Hill.

Austin, J. (1996). Risk and real estate investment: An international perspective. Journal of Real Estate Research, 11(2), 117-130.

Baas, D. (2010). Approaches and challenges to political risk assessment: The view from export development Canada. Risk Management, 12.

Beeman, D. R. \& Taoka, G. M. (1991). International business: Environments, institutions, and operations. USA: Harpercollins College Div.

Best, A.M. (2019). Market Segment http://www3.ambest.com/bestweekpdfs/sr516553119175bfull.pdf, Erişim Tarihi 03.01.2020.

Can, E. (2012). Uluslararası işletmecilik teori ve uygulaması. İstanbul: Beta Yayınevi.

Collinson, S., Hodgetts, R. M., Rugman, A. M (2006). International Business. England: Pearson Education.

Correia, R., Población, J. \& Restrepo, D. (2012). Political risk and corporate investment decisions. Universidad Carlos III de Madrid, Departamento de Economía de la Empresa, Madrid.

Costa, L. P. D. S., \& Figueira, A. C. R. (2017). Political risk and internationalization of enterprises: A literature review. Cadernos EBAPE BR, 15(1), 63-87.

Czinkota, M., Ronkainen, I. (2013). International marketing. USA: Cengage Learning.

Çavuşgil, S. T., Knight, G., Riesenberger, J. R., Rammal, H. G. \& Rose, E. L. (2008). International business. Australia: Pearson.

Çilingir, S. (2004). Doğrudan yabancı sermaye yatırımlarında politik risk ve türkiye açısından değerlendirmesi. Yüksek lisans tezi, Dokuz Eylül Üniversitesi.

Daft, R. D. (2010). Management. USA: Cengage Learning EMEA.

DEIK, (2011). 10 soruda politik risk sigortası. İstanbul. Erişim Tarihi: 10.08.2015 https://www.deik.org.tr/Contents/FileAction/3541.

Dess, G. G. \& Miller, A. (1996). Strategic management. USA: Mc Graw-Hill. 
Doz, Y. L. \& Prahalad, C. K. (1980). How MNCs cope with host-government intervention. Harvard Business Review, 58(2).

Goyal, A. \& Goyal, M. (2011). Business environment. India: FK Publications.

Günal, M. (2006). Para, banka ve finansal sistem. Ankara: Yeni Dönem Yayıncılık.

Haendel, D. (2018). Foreign investments and the management of political risk. USA: Routledge.

Hernández Gutiérrez, J. C. (2019). The political risk analysis. International Security Studies Group, $1-16$.

Hollensen, S. (2007). Global marketing: A Decision-oriented Approach. United Kingdom: Pearson Education.

Hollensen, S. (2014). Global marketing. United Kingdom: Pearson Education.

Hub Guides. (2013). http://outhwaiteandchavda.com/public/guide\%20to\%20diversification.pdf, Erişim Tarihi: 02.01.2020).

John, A., \& Lawton, T. C. (2018). International political risk management: Perspectives, approaches and emerging agendas. International Journal of Management Reviews, 20(4), 847-879.

Karabay, M. (1997). Uluslararası inşaat sektöründe politik risk ve bulanık kümeler yardımıyla analizi için bir yöntem önerisi. Doktora Tezi, İstanbul Teknik Üniversitesi, Fen Bilimleri Enstitüsü, İstanbul.

Lee, K., \& Carter, S. (2012). Global marketing management. UK: Oxford University Press.

Loikas, A. (2003). A government analysis of political risk: exploring equilibrium, instability and pluralism at the local, national and supranational level in Europe, Turku School of Economics and Business Administration, Finland.

Mayer, H. (2017). Political risk insurance and its effectiveness in supporting private sector investment in fragile states. The LSE-Oxford Commission on State Fragility, Growth and Development. $\quad$ https://www.theigc.org/wp-content/uploads/2018/05/Political-riskinsurance.pdf

Mckellar, R. (2010). A short guide to political risk. United Kingdom: Gower Publishing, Ltd.

Menipaz, E., \& Menipaz, A. (2011). International business: Theory and Practice. USA: Sage.

MIGA. (2013). World Investment and Political Risk. https://www.miga.org/ documents/WIPR13.pdf.

Musonera, E. (2008). Country risk factors: An empirical study of fd1 determinants in SSA. Journal of International Management Studies, New Mexico.

Onkvisit, S., \& Shaw, J. (2004). International marketing: Strategy and theory. London: Routledge.

Robock, S. H. (1971). Political risk: Identification and assessment. Columbia Journal of World Business, 6(4), 6-20.

Robock, S. H., Simmonds, K. \& Zwick, J. (1989). International business and multinational enterprises. Irwin: Homewood, IL.

Root, F. (1972). Analyzing political risks in international business. The Multinational Enterprise in transition. USA: Darwin Press.

Root, F. R. (1987). Entry strategies for international markets. USA: Lexington Books. 
Simon, J. D. (1982). Political risk assessment: Past trends and future prospects. Columbia Journal Of World Business, 17(3), 62-71.

Simon, J. D. (1984). A theoretical perspective on political risk. Journal of International Business Studies, 15(3), 123-143.

Suder, G. (2009). International business. India: C\&M Digitals.

Sun, M. H., \& Liu, H. T. (2018). An exploration of how political risk components affect the stock volatility considering ICRG and GARCH Model. In 4th Annual International Conference on Management, Economics and Social Development.

Zembri-Mary, G. (2019). Project risks: Actions around uncertainty in urban planning and infrastructure Development. USA: John Wiley \& Sons.

https://icsid.worldbank.org/en/Documents/ICSID_AR19_EN.pdf, Erişim Tarihi: 02.01.2020.

http://www.hurriyet.com.tr/ekonomi/lahey-mahkemesi-rusya-ya-50-milyar-dolar-ceza-kesti26905261, Erișim Tarihi: 02.01.2020.

http://www.mfa.gov.tr/uluslararasi-yatirim-anlasmazliklarinin-cozum-merkezi-_internationalcentre-for-settlement-of-investment-disputes-icsid_.tr.mfa, Erişim Tarihi: 03.01.2020.

http://www.ntv.com.tr/ekonomi/fransa-ve-belcika-rusyanin-mal-varliklarina-el-koyma-kararialdi,FxcOWzz6okyNWfiZUHieyw, Erişim Tarihi: 04.01.2020. 